\title{
A Brief Overview of Despotic Leadership Research
}

\author{
ALEENA MUKARRAM \\ Department of Business Administration, \\ Foundation University, Islamabad, Pakistan. \\ Email: Aleena.mukarram@fjwu.edu.pk \\ Dr. SAJJAD HUSSAIN \\ Department of Business Administration, \\ Foundation University, Islamabad, Pakistan. \\ Email: sajjad.hussain@ fui.edu.pk

\section{MEHWISH ALI KHAN} \\ Faculty of Management Sciences, \\ Riphah International University, Islamabad, Pakistan. \\ Email: Mehvish.ali@riphah.edu.pk
}

\begin{abstract}
The present study is an attempt to give a brief overview of despotic leadership research in a chronological order. Starting from the pre-historic era, the study links the concept of despotic leadership with Greek era and explains its existence in other domains which includes sociology and political science. It briefly addresses questions like how despotic leadership evolved from the broader construct of destructive leadership. What are the different types of destructive leaders and how despotic leadership differs from other type? It also covers different consequences of the despotic leadership with multiple themes. The study deeply analyzes the integration of despotic leadership research with multiple behavioral and attitudinal work-related outcomes. Finally, current trends and future directions are proposed for further scientific and logical validation.
\end{abstract}

Keywords: Despotic leadership, Historical Review, Multiple Dimensions, Current and Future Trends.

\section{Introduction}

Aristotle, the most famous Greek philosophers of all times, was the first one to describe the concept of leadership 2400 years ago. Leadership is a widely discussed and well known concept with critical administrative ramifications(Antonakis et al., 2012; Bass \& Bass, 2009; Yukl \& Mahsud, 2010). It's research has seen fast developments with a huge number of publications of articles and books (Batistič et al., 2017). The core of leadership phenomenon lies in determining clear objectives and its afterward implications on followers who seek those objectives(Shamir et al., 1993). Interestingly, the same essence is followed by a destructive leader, but antagonistically, which means destructive leaders identify negative goals and then influence followers to chase them. Society's enthrallment with scandalous super villains has created incredible academic interest in understanding damaging effects of bad leadership (Krasikova et al., 2013; Schyns \& Schilling, 2013).Destructive leader is a harsh reality of organizational life. Deceiving CEOs and their infamous corporate scandals arouse thoughts on the "dark" traits of organizational leaders. An increase in destructive leadership studies is also significant because of the costs associated with it. For instance, according to a research, abusive supervision negatively impact an estimated $13.6 \%$ of workers in USA alone mainly due to employee absenteeism and employee turnover. Furthermore, the deterring impacts of bad leadership on employees are very extreme(Harvey et al., 2007). 
Destructive leadership is a broad construct and its defined as "The systematic and repeated behavior by a leader, supervisor or manager that violates the legitimate interest of the organization by undermining and/or sabotaging the organization's goals, tasks, resources, and effectiveness and/or the motivation, wellbeing or job satisfaction of subordinates"(Einarsen et al., 2007).Destructive behavior of those in leadership positions are often not labelled as leaders but received other names e.g. abusive, bad or authoritative leadership (Tepper, 2000). In recent times many categorizations of destructive leadership have been studied which includes: Machiavellian(Christie\&Geis,1970), Autocratic(Kipnis et al.,1981),Narcissistic leadership(De Vries \& Miller, 1985),Flawed leadership(Hogan et al., 1994),Derailed leadership(McCall \& Lombardo, 1983; Shackleton, 1995),Toxic leadership(Lipman-Blumen, 2005),Impaired managers (Lubit,2004),Supervisor undermining(Greenbaum et al.,2015),Self-serving leadership(Decoster et al.,2014; Rus et al.,2010),Hubristic leadership(Sadler-Smith, 2018)and Despotic leadership(De Hoogh \& Den Hartog, 2008). Despotic leadership is unarguably the most conceited and damaging style of leading. It was found in one of the study that despotic leadership strengthens the impact of organizational deviance which mainly includes stealing and minimizing efforts in performing day to day tasks at workplace (Erkutlu \& Chafra, 2018). Despotic leaders negatively affect the job performance level, satisfaction and emotional well-being of employees at workplace as this phenomenon is unbearable for most of the employees (Raja,Haq,Clercq \& Azeem,2019). Bullying behavior acts as an antecedent of despotic leadership in one of the study where despots through moral emotions of anger and disgust tend to manipulate the work environment negatively (Syed et al., 2020). Social exchange theory (Balu, 1964) tend to better explain the logical reasoning of above-mentioned negative work-related outcomes of employees at work by providing necessary theoretical support and underpinning. This theory proposes that in social exchanges, parties respond by mimicking the way they are being treated by the other parties involved in the exchange relationships. In case of despotic leaders, followers respond by exhibiting emotional and psychological distress and decreased levels of satisfaction, performance and creativity as a reciprocity of what they have received from their bad and toxic leaders.

This particular study aims to provide a brief overview of despotic leadership as this leadership type is attaining scholarly attention worldwide but still has scope for further exploration(Nauman et al., 2018; De Clercq et al., 2018). This study is divided into six sections. First section describes brief historical background which mainly involves how this concept emerged from history specifically from philosophical and political science perspective to modern management sciences literature. Second section discusses theoretical significance by highlighting different constructs related to despotic leadership their similarities and differences and major overarching theories in this regard. Third section consists of multiple themes including belief system of a despot and the impact of it on attitudinal and behavioral work-related outcomes of employees. Fourth section includes methodology for conducting review paper, fifth involves current and future trends. Finally sixth section includes discussion and conclusion.

\section{Brief Historical Background of Despotic Leadership}

"The possession of unlimited power will make a despot of almost any man. There is a possible Nero or cruel ruler in the gentlest human creature that walks" (Thomas Bailey, Leaves from a notebook).

Despotism is derived from a Greek word "despot" which means "master" or "one with absolute power." It refers to an arrangement of administration where a solitary being rules with supreme force. The term has been utilized to depict various types of rulers, from local chieftain, tribal leader to king or emperor. The term has been utilized to depict numerous rulers and governments in Greek folklore.

Colonial or communist countries soon after their independence from their subsequent oppressors had high expectations, but unfortunately these expectations of true freedom from the brutal clutches of their rulers proved futile(de Vries, 2006). Reason was the stark differences between wealth and poverty, prevalence of corruption and social institutions' and disintegration. These factors forced people to willingly obey despotic 
regimes. The search of people for their messiahs who would award them economic and political salvation paved way for despotism.

From Greek emperors to modern despots, the historical background of numerous tyrannical systems is a line of caution stories, reminding that each culture needs to assemble and keep up solid balanced governance against the maltreatment. Without these protections, any system, regardless of how kind, can approach to dictatorial guideline.

The term Despotism has been used interchangeably used with tyranny since $18^{\text {th }}$ century. However as a matter of fact these terminologies differ.

\section{Difference between Tyranny and Despotism}

"Despotism while being authoritarian and arbitrary, is legitimate if not legal in some countries, whereas tyranny, in the most rigorous sense, is authoritarian and arbitrary and which is illegitimate and illegal because it is exercised not only without but against the will of the individuals and also scorns fundamental human rights."(Turchetti, 2008). A ruler with unlimited despotic power may become tyrant. But it is not necessary that every tyrant is a despot. A despotic ruler can be compassionate, if he rules for the benefit of the subjects.

Management sciences have many constructs similar to despotic leadership which includes: authoritarian personality(Altemeyer, 1988), bureaupathic individual(Thompson, 1965)and abrasive personality(Levinson, 1978) etc. These constructs provided rich legacy of behavioral descriptions. They have striking similarities with despotic leadership and they also paved way for the concept of despotic leadership in management sciences literature.

\section{Brief Theoretical Background}

Since 1930s many prominent theories have been developed shaping leadership research (House \& Aditya, 1997). A theory in organizational science is aimed to describe an organizational perspective that guides humanistic action(Hussain \& Dar, 2020). Researchers have studied a number of constructs that is covered under destructive leadership. Preliminary work on destructive leadership started with the phenomenon of abusive supervision and it has received substantial attention since the 2000s. An impactful work in this regard is produced by Tepper in 2007 and by Aryee, Chen, Sun, and Debrah in 2007. Some other destructive leadership constructs are as under:

Table 1: Description of Destructive Leadership Constructs

\begin{tabular}{|ll|}
\hline Construct & Definition \\
\hline Abusive supervision & $\begin{array}{l}\text { Subordinates' impression of the degree to which } \\
\text { supervisor is involved in verbal and non-verbal } \\
\text { abuse at workplaces (Tepper, 2000). }\end{array}$ \\
& $\begin{array}{l}\text { It involves administrative style that includes } \\
\text { playing top favorite and disparaging devotees } \\
\text { (Ashforth, 1994, 1997, 2003; Reed \& Bullis, }\end{array}$ \\
2009) & $\begin{array}{l}\text { Authority that emphasizes personal objectives } \\
\text { over devotees' needs and hierarchical } \\
\text { destinations; it also involves misdirection and } \\
\text { pressure (Barling, Christie, \& Turner, 2008; Bass } \\
\text { and Steidlmeier, 1999). }\end{array}$ \\
\hline
\end{tabular}




\begin{tabular}{|c|c|}
\hline Personalized Charismatic Leadership & $\begin{array}{l}\text { They deliberately chose strategies to create a } \\
\text { desired } \\
\text { Picture among followers and spot focuss in an } \\
\text { agreeable, feeble position to accomplish } \\
\text { individual or authoritative targets (Ferris et al., } \\
\text { 2007) }\end{array}$ \\
\hline Strategic Bullying & $\begin{array}{l}\text { Leaders in this case are regularly spurred by } \\
\text { authoritative objectives, they mainly follow self- } \\
\text { serving objectives(e.g., "making a realm, winning } \\
\text { titles, being perceived as a maestro, being seen as } \\
\text { a deliverer (Ma et al., 2004) }\end{array}$ \\
\hline Managerial Tyranny & $\begin{array}{l}\text { Authority block capacity to build up and keep up } \\
\text { relational connections, business related } \\
\text { achievement, and ideal standing (Duffy, Ganster, } \\
\text { \& Pagon, 2002, p. 332) }\end{array}$ \\
\hline Leader Incivility & $\begin{array}{l}\text { It involves utilization of "low-force" misconduct } \\
\text { with questionable aim to hurt the followers, } \\
\text { disregarding work environment standards. } \\
\text { Uncivil practices are naturally inconsiderate and } \\
\text { rude, showing an absence of respect for other } \\
\text { people (Andersson \& Pearson, 1999, p. 457) }\end{array}$ \\
\hline Despotic & $\begin{array}{l}\text { This style is "presumptuous and shifty of others" } \\
\text { since it depends on close predominance and } \\
\text { conduct that serves the personal circumstance of } \\
\text { the leader (De Hoogh and Den Hartog, 2008, p. } \\
\text { 298) }\end{array}$ \\
\hline
\end{tabular}

Keeping in view the above-mentioned leadership styles it is worthwhile to explain that there are many overlaps between different leadership styles. But still there are distinctive differences that need to be considered. Some of the differences that make despotic leadership construct different from other destructive leadership types are as under:

Despotic leaders require ultimate obedience and submission from their subordinates. Such leaders are more demanding and controlling and they behave unsympathetically toward their followers (Schilling, 2009). They are arrogant, ethically devastated and have low moral principles (De Hoogh and Den Hartog, 2008). The significant spotlight is on severe, embarrassing, and hostile practices toward the subordinates and no reference is made to the honesty and moral character. Moreover the despotic leadership style unlike other leadership types includes practices that reflect selfish thought processes intended to control, use, and endeavor supporters. The emphasis of despots is on their own benefit, that's why they not just act in exploitative and socially unconstructive manners but likewise they neutralize the real interests of the followers by participating in deceitful and ethically inaccurate self-serving practices (Aronson, 2001). Other administration types, for example, petty tyranny, abusive supervision and supervisor undermining can't cover the particular impacts that a despot have on their followers.

Similarly tyrannical leadership differs from despotic leadership (de Vries, 2006). According to De Vries, tyrants oppress subordinates but they are beneficial for the organizational performance. The fact is that tyrannical leaders are exceedingly valuable in attaining organizational goals. Tyrants achieve their assigned goals and help organizations reach pinnacle of their performance but on the expense of psychological wellbeing of their subordinates. 
Table 2: Brief Over view of Positive Leadership Theories

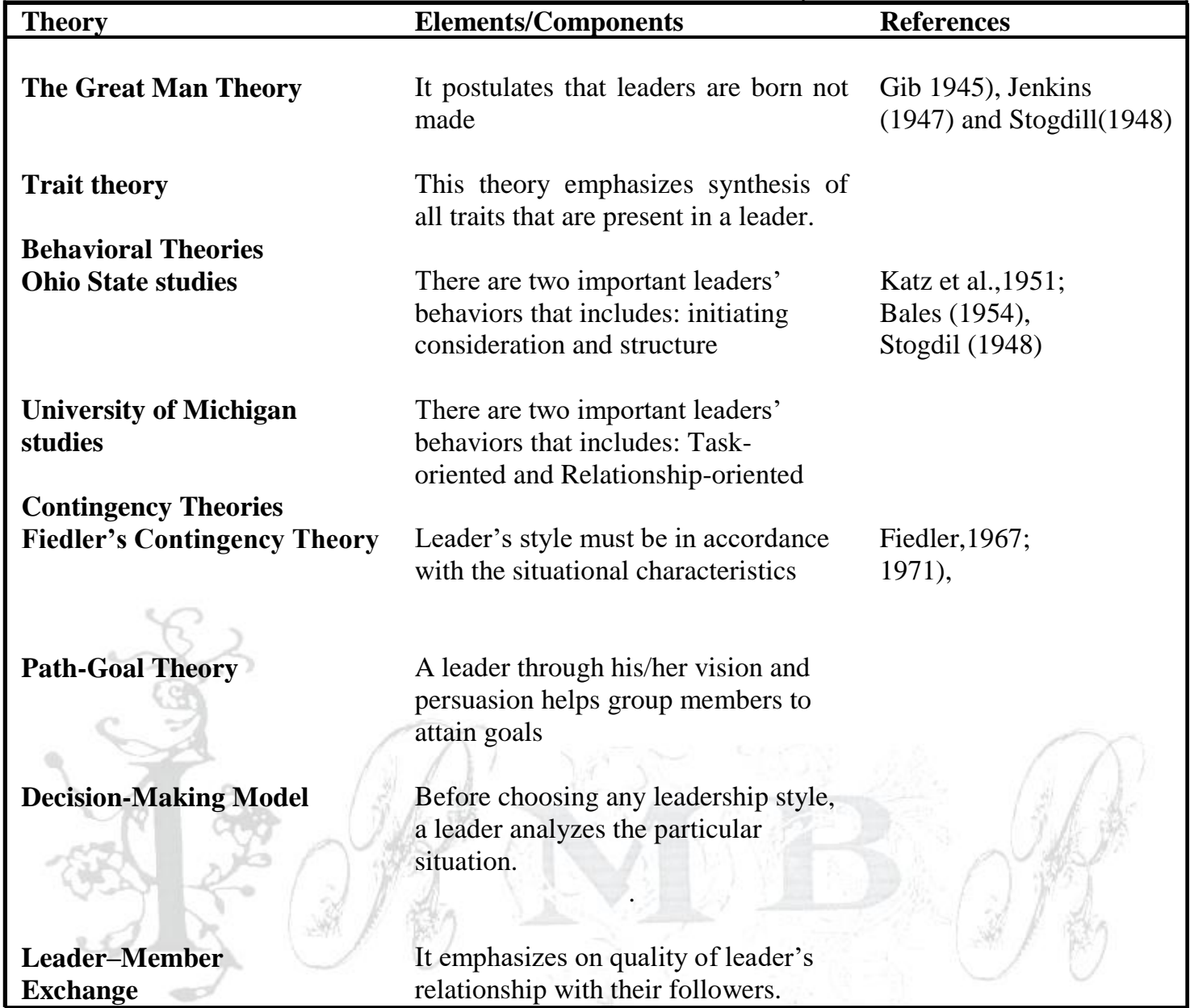

Table 3 : Major Overarching theories of destructive leadership

\begin{tabular}{|l|l|}
\hline Theory & Reference \\
\hline Social exchange theory & George Homans in 1958 \\
\hline Power/dependence theory & Richard Emerson in 1962 \\
\hline Moral exclusion theory & Opotow's in 1990. \\
\hline Social learning theory & Bandurs in 1964 \\
\hline Social information processing theory & Joseph Walther in 1992 \\
\hline Attribution theory & Fritz Heider in 1958 \\
\hline Role theory & Eagly and Wood in 1999 \\
\hline Conservation of resources theory & Hobfoll's in 1998 \\
\hline Self-gain view & Thau et al., in 2007 \\
\hline Self-regulation impairment view & Roy Baumeister in 1994 \\
\hline Reactance Theory & Jack Brehm in 1966 \\
\hline Demand-control theory of stress. & Karasek in 1979 \\
\hline
\end{tabular}




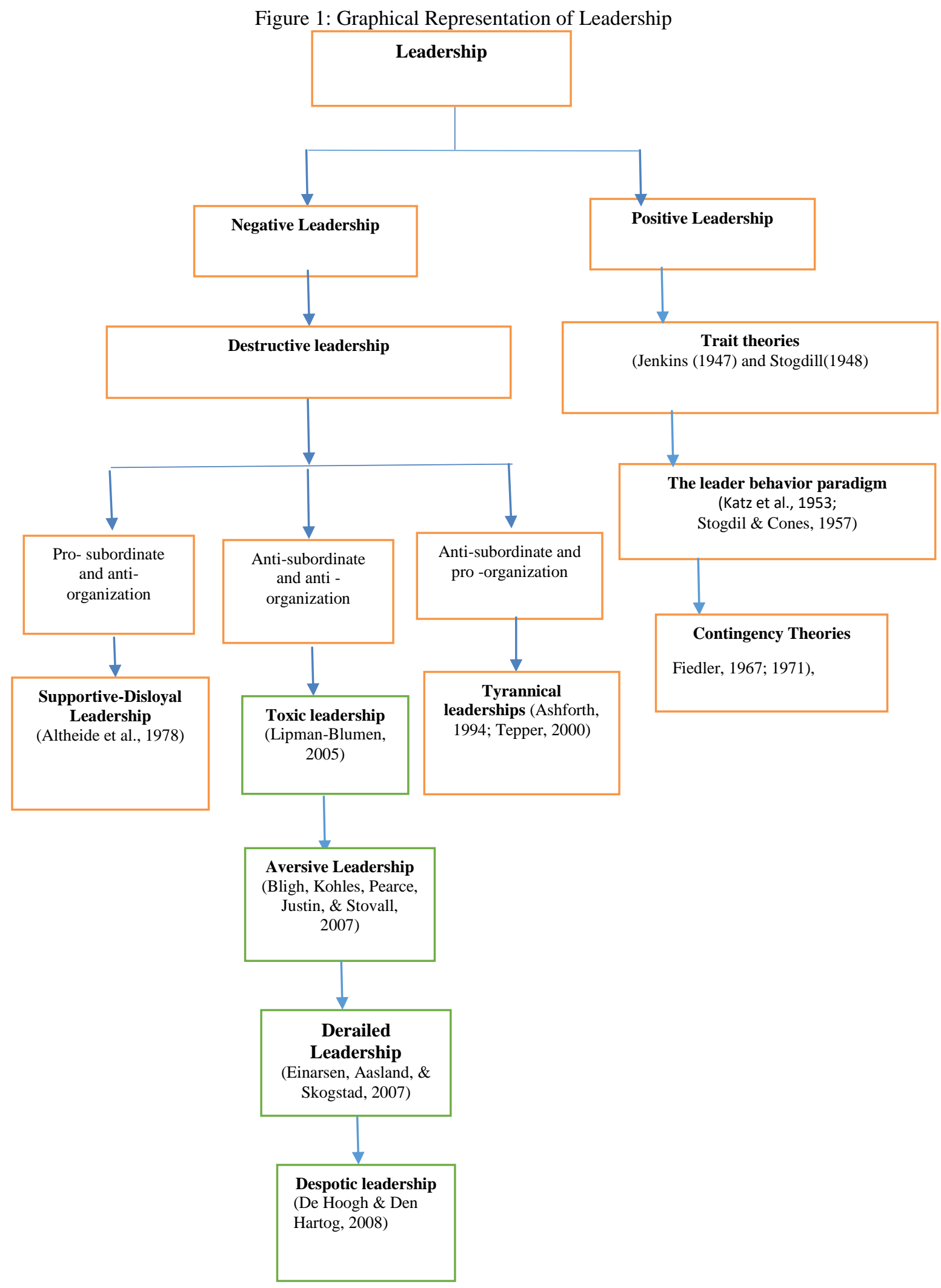




\section{Multiple Themes}

The desire for power pushes a despot past the limits, making them forsake regard for people and act in manner that stop others from carrying on with their lives normally. Despotic leaders create great hindrance in achieving equity, distinction and growth of the human potential.

\section{Belief about Subordinates}

As per Ashforth in his conspicuous work on "Petty Tyranny in Organizations". He contends that a despot's initiative stems from the conviction proposed by McGregor (1960) in his acclaimed "Hypothesis X". This hypothesizes that there is an intrinsic conviction of leaders with respect to the overall working disposition of their subordinates at work environments. Supervisors feel that a normal employee would prefer not to work as they are lazy reckless, and are least keen on gathering their cutoff times and objectives at work. Fiman (1974) contends that those administrators who are steadfast adherents of hypothesis X are seen as least helpful and stricter by their subordinates. It was additionally contended by McGregor that hypothesis $\mathrm{X}$ gives a solid establishment to legitimate and coercive administration styles.

\section{Belief about Self}

Interestingly, low self-confidence was found to be one of the leading causes of coercive actions of authoritative leaders (Kipnis, 1976). According to Kipnis, there is a negative relationship between managerial confidence and oppression as a leader. This means that lower confidence directs more coercive and authoritarian actions of a leader. In other words, personal insecurities pave way for over-controlling others (Vries \& Millr, 1984).

\section{Preference for Action}

It is said that most of the political dictators have a will to impose power (Ray, 1976). On the same footing House (1988) proposed that those individuals having higher desire for attaining power, want to experience gaining power as compared to those with a lower tendency at workplace. Authoritarianism postulates dominance towards one inferior. These core concepts of directedness, dominance and desire to subjugate inferiors to gain power were not only prevalent previously in management sciences but they also provide sufficient theoretical support for a novel phenomenon of leadership i.e., despotic leadership.

\section{Attitudinal Outcomes and Behavioral Outcomes}

There are different attitudinal and behavioral outcomes of despotic leadership style. Some of them are as under:

To avoid the wrath of leaders, followers adopt certain strategies including ingratiation which equip employees to avoid the rage of a despotic leader and also help them to bear the hardships inflicted by them (De Clercq, Fatima \& Jahanzeb, 2018).

Stress and psychological deterioration of the subordinates are the most significant and most researched outcomes of despotic leadership. It was revealed in one of the studies conducted in public sector financial institutions that trauma and angst among employees related to humiliation and bias by their higher-ups which is also perceived as organizational injustice, leads to phenomenal failure(Baig,Hussain \& Hussain,2020). Elevated level of anger and frustration was found to be followed by a higher level of insecurity, frustration and detachment from work under bad leadership (Bhandarkar \& Rai, 2018). Supervisor's abusive behavior triggers burnout and counterproductive work behaviors among the employees while Islamic Work Ethics plays a critical role in minimizing the negativity of the dark triad of a leader (Tahir, Khan\& Hussain, 2020). Despotic leadership induces emotional exhaustion among employees 
which later on negatively influence their psychological well-being and family life (Ernst, Kossek \& Ozeki, 1998). As a defensive mechanism employees tend to avoid their toxic leaders or maintain minimum interaction with them (Lubit, 2004). Sometimes they seek to find easier and less efficient ways of doing things and become unethical (Schilling, 2009). Employees at the workplace mostly seek stress preventive resources which safeguard them against the negative work environment. One of such preventive resource is group cohesion. Group cohesion is one of such resources and it plays an important role in increasing psychological capital, thus encouraging employees to share the knowledge that is otherwise hindered by abusive supervision (Hussain et al., 2020). Emotional intelligence plays a similar role in buffering the negative impact of work interference and negative emotions on counterproductive work behaviors (Sarmad et al., 2002). Perception meaningfulness of tasks by employees and its linkage with overall organizational goals greatly elevates their creativity level (Ahmad, Hussain, Sulehri \& Hussain, 2020). Despotic leaders are viewed as a burden at workplaces. A study conducted by Erkutlu and Chafra, (2017) findings suggested that despotic leadership leads to higher levels of employee deviance from their organizational goals and objectives and minimizes their relevant identification related to their job. In other words, organizations should be careful in treating their subordinates as the perception of subordinates in case of a bad working environment increases organizational deviance. Some other studies suggested that the darker aspect of despotic leadership becomes more implicit in the context which favors or promotes its negativity such as high LMX and high perception of politics (POP) (Naseer et.al, 2016). Follower's optimism, trust, loyalty, and organizational citizenship behaviors largely depend on their leadership, in case of despotic leadership such extra-role performances from employees are rarely triggered (De Hoogh \& Den Hartog, 2008).

Job stress makes employees suffer mentally and physically. Sometimes it is triggered by the employees' inability to share concerns about their job stress to their supervisors (De Clercq, Haq, \& Azeem, 2017). The prompting role of stress among female employees was found to be more severe as compare to their male counterparts (Eagly \& Crowley, 1986; Leslie et al., 2013). This urge them to help colleagues suffering from despotic leadership. Islamic work ethics strongly influence the helping behaviors of employees towards their affected colleagues as Islamic work ethic postulates peer support (Ali, 2005; Tufail et al., 2020). Helping behaviors play a significant role to mitigate the negativity associated with bad leaders in work environment. Mostly employees are reluctant to report because of the fear of being caught (Aronson, 2001)

Table 4: Brief Overview of Despotic Leadership

\begin{tabular}{|c|c|c|}
\hline Level & Nature & Negative Effects of Despotic leadership \\
\hline & Attitudes & $\begin{array}{ll}\text { - } & \text { Turnover intentions (Clercq et al., 2020) } \\
\text { - } & \text { Employee Family life (Nauman,Fatima \& Haq,2018) }\end{array}$ \\
\hline Personal & Behaviors & $\begin{array}{ll}\text { - } & \text { Performance(Naseer et al., 2016) } \\
\text { - } & \text { Helping behavior(De Clercq et al., 2019) } \\
\text { - } & \text { Employee Performance(Jabeen \& Rahim,2021) } \\
\text { - } & \text { Job performance(Raja et al., 2019) } \\
\text { - } & \text { Dissatisfaction(Islam et al., 2020) }\end{array}$ \\
\hline $\begin{array}{l}\text { Social } \\
\text { Exchange }\end{array}$ & $\begin{array}{l}\text { Interpersonal } \\
\text { Organizational }\end{array}$ & $\begin{array}{ll}\text { - } & \text { Workplace Status(De Clercq,Fatima \& Jahanzeb,2019) } \\
\text { - } & \text { Organizational deviance(Erkutlu \& Chafra,2017) } \\
\text { - } & \text { Organizational Career Growth(Rasool et al., 2018) }\end{array}$ \\
\hline
\end{tabular}

Despotic leaders were also found to indulge in immoral acts of bullying and humiliating employees (Syed et. al., 2020). Bullying specifically prevails in a high-power distance culture as such cultures provide a fertile ground and leaders use their power against subordinates. Despots can also involve in fraudulent and morally incorrect activities against the legitimate interests of organizations (Aronson, 2001). The following tables indicate that despotic leadership is associated with several negative outcomes which can be 
categorized into psychological- and performance-related outcomes along with their respective research models. These tables are as under:

Table 5 : Brief Overview of Despotic Leadership -Perspectives and Ideologies

\begin{tabular}{|c|c|c|c|}
\hline Referent & Perspective & Model & Ideology \\
\hline Relational & $\begin{array}{l}\text { Behavioral } \\
\text { outcomes }\end{array}$ & $\begin{array}{l}\text { - } \begin{array}{l}\text { Social exchange } \\
\text { theory } \\
\text { - } \\
\text { Conservation of } \\
\text { resource theory }\end{array}\end{array}$ & $\begin{array}{l}\text { - Despotic leadership is negatively } \\
\text { influences three employee outcomes } \\
\text { i.e., Job performance, OCB and } \\
\text { employee creativity. } \\
\text { - Supportive co-workers steers away } \\
\text { employees from turn over intentions } \\
\text { and despotic leadership } \\
\text { Work-family trouble } \\
\text { subordinates' non-work lives }\end{array}$ \\
\hline Morality & $\begin{array}{l}\text { Related to } \\
\text { sabotaging } \\
\text { moral values }\end{array}$ & $\begin{array}{l}\text { - Social exchange } \\
\text { theory } \\
\text { - Conservation of } \\
\text { resource theory }\end{array}$ & $\begin{array}{l}\text { - Despotic leadership damages } \\
\text { satisfaction and morality levels of } \\
\text { employees by pushing them towards } \\
\text { deviance behaviors }\end{array}$ \\
\hline Religiosity & $\begin{array}{l}\text { Islamic work } \\
\text { ethics }\end{array}$ & $\begin{array}{l}\text { - Social exchange } \\
\text { theory } \\
\text { - Conservation of } \\
\text { resource theory }\end{array}$ & $\begin{array}{l}\text { - Islamic work ethics (IWE) was } \\
\text { found to cushion the beneficial } \\
\text { outcome by reducing occupation } \\
\text { disappointment. }\end{array}$ \\
\hline $\begin{array}{l}\text { Cultural } \\
\text { Perspective }\end{array}$ & $\begin{array}{l}\text { Power Dist } \\
\text { Orientation }\end{array}$ & . & $\begin{array}{l}\text { - Despotic leaders' spikes workers' } \\
\text { upward ingratiatory conduct, and } \\
\text { this conduct is more unmistakable } \\
\text { among representatives with more } \\
\text { significant levels of power- distance } \\
\text { orientation. }\end{array}$ \\
\hline
\end{tabular}

\section{Methodology}

Organized efforts were made to identify despotic leadership research that was available as of December 2020 in order to provide evidences that could be compared and synthesized. The goal was to formulate a review study that could represent the empirical despotic leadership literature. The following research strategies were used:

Google and Google Scholar were utilized for the hunt of studies that referred to quantify papers for explicit styles of destructive leadership. Academic information bases were looked through that included ProQuest Dissertations, Theses, Web of Science, PsycINFO for articles, book parts, gathering papers, specialized reports, and working papers. Similarly reference lists of many relevant articles were also researched for identifying further useful studies. One of the selection criteria for choosing most relevant and appropriate studies included searching for the terms that included "damaging" "oppressive" "authority" "tyrant" "tyranny" "destructive leader" "toxic leadership and "abusive leadership/supervision "related articles. Certain inclusion criterias were followed for selection of papers while conducting this study. The main reason for following inclusion criteria was to standardize this brief overview as much as possible and to enhance the validity of the study. Some of the quality assurance inclusion criteria includes following: Only those research articles were selection where the phenomenon of destructive leadership was studied not only empirically but also in consistence with its conceptualization. Those studies were selected that surveyed employees and their perceptions about their leaders. Similarly only those papers were selected which were 
written in English. Earliest available data was included and it was also ensured that no overlap occurs during this process. Approximately 100-150 articles were studied among which 110-120 relevant papers were selected and referred accordingly during the formulation process of the study. Since the phenomenon of despotic leadership is still in its initial phases of infancy and limited research work is done so far, therefore nearly 15-20 papers(research papers, dissertations, book chapters, technical reports working papers and conference papers )were downloaded that specifically addressed despots and despotic leadership at workplaces.

The leader-follower relationship also known as a dyadic relationship is mainly measured in leadership. Each theory views the dyadic phenomena from different perspectives. Dyad or Dyadic relationships measure a variable from two perspectives which lead to a complete view (Krasikova \& LeBreton, 2012; Bass, 2008). Dyadic data can be collected from either one leader and one follower or one leader and multiple followers (Gooty \& Yammarino, 2011). In addition self-report measurement method, time-lagged studies are also used for recording responses. Time-lagged method for data collection is considered as one of the most reliable method, as after careful examination of the literature, it was found that common method variance is one of the potential cause of biases and errors in research studies. One of the solutions proposed by (Podoskoff, MacKenzie \& Lee, 2003) in their conspicuous research paper "Common Method Biases in Behavioral Research: A Critical Review of the Literature and Recommended Remedies" after rigorously assessing the research settings, was conducting "Time-lagged studies". Time-lagged studies instead of one short or cross sectional studies minimizes the occurrences of biases and errors in research findings. Some of such biases and errors which can potentially manipulate and damage the reliability and validity of research findings in the absence of a time-lagged research design are as under:

Table 6: Description of Potential Sources of Biases and Errors

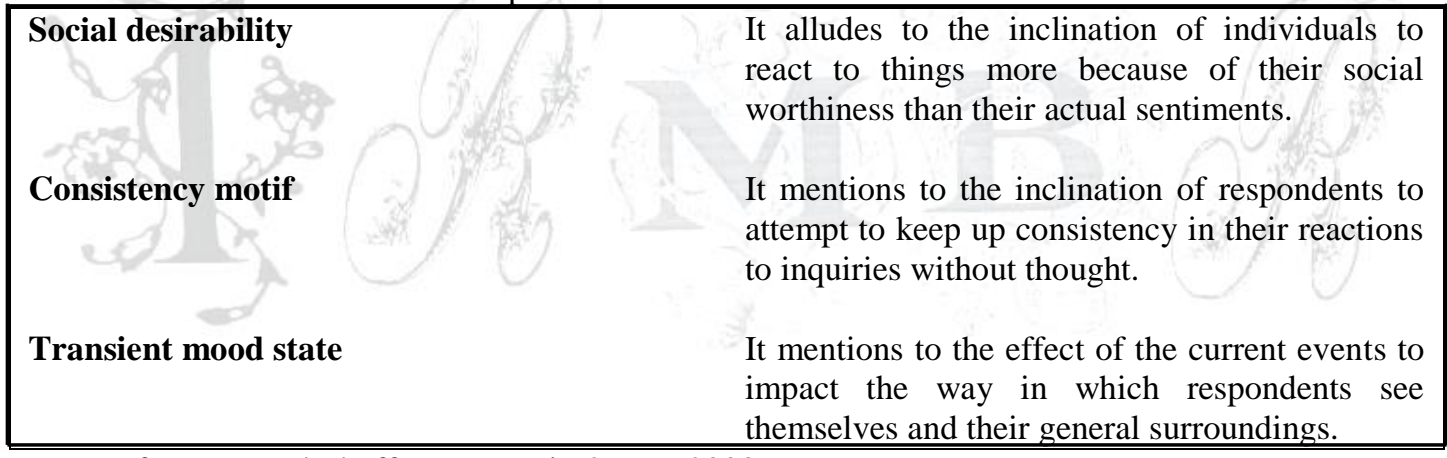

Note: Reference: Podsakoff, MacKenzie \& Lee, 2003.

In Quantitative studies, there are different scales for assessing negative leadership. One of the most commonly used scale in this regard is abusive supervision (Tepper, 2000). While the dominant part of studies utilized the full 15 question adaptation, a few investigations (Baumeister et al., 2001) utilized more limited forms going from 3 to 13 questions for assessing negative leadership. Ensuing variables and investigations verified that despotic leadership could be close fistedly caught by the six-item scale. This scale was created by Annebel H.B. De Hoogh and Deanne N. Den Hartog. It was developed on the basis of items formerly proposed by Hanges and Dickson (2004). The items assessing Despotic leadership includes following:

I. My supervisor is punitive; has no pity or compassion.

II. My supervisor is in charge and does not tolerate disagreement or questioning.

III. My supervisor gives orders and acts like a tyrant or despot; imperious.

IV. My supervisor tends to be unwilling or unable to relinquish control of projects or tasks.

V. My supervisor expects unquestioning obedience of those who report to him/her is vengeful.

VI. My supervisor seeks revenge when wronged.

(Annexure-A- Despotic Leadership items) 


\section{Current Trends' Summary}

Studies conducted on despotic leadership had largely focused on the leader's attitudinal and behavioral outcomes. The summary of current trends in despotic leadership literature shows the following:

Table 7 : Description of Independent Variables (IVs) and Consequences of Despotic Leadership

\begin{tabular}{|ll|}
\hline Independent Variables (IVs) & Consequences \\
\hline Despotic Leadership & $\begin{array}{l}\text { Employees' turnover intentions } \\
\text { (De Clercq,Azeem,Haq \& Bouckenooghe, 2020) }\end{array}$ \\
Despotic leadership & $\begin{array}{l}\text { Organizational deviance } \\
\text { (Erkutlu \& Chafra, 2017) }\end{array}$ \\
Despotic leadership & $\begin{array}{l}\text { Bullying Behavior } \\
\text { (Syed et al. 2020) }\end{array}$ \\
Despotic leadership & $\begin{array}{l}\text { Performance,OCB and creativity. } \\
\text { (Naseer et al. 2016) }\end{array}$ \\
Despotic leadership & $\begin{array}{l}\text { Job Performance } \\
\text { (Nauman,Zheng \& Basit,2020) }\end{array}$ \\
Islamic work behavior & Helping behavior (DeClercq et al., 2019) \\
Despotic leadership & Performance, Satisfaction and Psychological \\
well-being. & (Raja et al. 2019) \\
Despotic leadership & $\begin{array}{l}\text { Job dissatisfaction and Organizational Deviance } \\
\text { (Islam et al. 2020) }\end{array}$ \\
Despotic leadership & $\begin{array}{l}\text { Employee outcomes } \\
\text { (Rasool et al., 2018) }\end{array}$ \\
& Workplace Status \\
(De Clercq,Fatima \& Jahanzeb,2019)
\end{tabular}

A despot can have a damaging impact on subordinates' morale and their tendency to contribute positivity towards their jobs. OCB towards individuals and towards organization (OCB-I and OCB-O) creativity, satisfaction, helping behavior, dissatisfaction, stress, deviance, and psychological and emotional well-being are badly affected.

These effects are strengthened with underlying mechanisms and processes. Some of the underlying mechanisms and their relevant moderators and mediators studied so far in despotic leadership researches includes: Political ineptness, ingratiation behavior, quality of work-family life, value congruence, organizational identification, self-concordance, moral emotion, perception of politics, leader-member exchange (LMX), employee engagement, employee trust, trait anxiety, exhaustion, Islamic work ethic, and power distance. 


\section{Actionable Agenda for Future Research}

Future research should explore some other under explored or unexplored horizons. For example, future research should focus how negative leader traits, attitudes, and behaviors can have constructive outcomes? (Yam et al., 2018; Zapata \& Hayes-Jones, 2019). The antecedents of despotic leadership require scholarly attention as limited research is done in this domain along with a lack of a unified theoretical framework. Similarly, identification of further moderators and mediators of underlying relationships of despotic leadership need to be explored. In this regard a new direction could be to examine the role of third party or bystanders and witnesses' reaction to the abusive supervision of a co-worker (Zhu, Song, Zhu \&Jhonson, 2019). The tendency of the followers to successfully break the spiral of despot through their psychological powers, thus managing to reach a reconciliation with a leader can be an interesting area for future research (Carlo \& Garcia, 2018). Psychological processes and their role in underlying despotic leadership relationship also need to be explored (Huyghebaert et al., 2018).

Another interesting avenue can be to understand how experience of a despot at workplace can damage the psychological well- being of subordinates and ruin their peace of mind thus leading them to indulge in paranoid thoughts (Freeman et al., 2011; Lopes et al., 2018).

The majority of destructive leadership studies at workplace have focused on leader-employee relationship. An interesting avenue in this regard can be to study leader's aggression between different leaders rather than between followers and subordinates. Currently many organizations are relying on teams of leaders to undertake various strategic tasks and projects (Wageman \& Hackman, 2010).

Another possible avenue can be to study impact of hierarchical position on the extent of devastation imposed by despotic leaders (Giessner \& Schubert, 2007). Assessing leadership style along with followers and environments is difficult and challenging. Broader systems approaches need to be incorporated to assess accurately the overall impact of a despot.

Different destructive leadership styles despite having differences also consists of certain level of overlaps in some of the concepts which makes it difficult sometimes to compare and contrast them. Future studies should also consider exploring this avenue by postulating comparative studies between different leadership styles and establishing the distinctiveness between them.

\section{Limitations}

There are some limitations in this study that should be carefully regarded.

One of the limitation is that management sciences journals were focused mainly for the phenomenon of despotic leadership which may have a possibility of excluding research and theory on this topic flourishing in other domains. For example despotic leadership phenomenon also occurs in Political science, Sociology, Education sector and Public Sector. Although this brief overview tried to provide a unifying perspective but a better comprehension can be obtained by analyzing and comparing a broader perspective provided by different domains and academically diversified subjects.

Second possible limitation is that although rigorous efforts were put to include research studies published on despotic and to provide brief but comprehensive overview, however there is a possibility that some of the studies got excluded because of limitations of absolute access of all research journals and human error.

\section{Discussion}

The previous few years have seen consistent developments in the literature regarding destructive leadership. It is perhaps the genuinely notable and upsetting phenomenon which subordinates can insight at 
work. Numerous studies have identified many terminologies related to bad/negative/destructive leadership styles but among them despotic leadership is very much novel as well as an under-explored and is successful in achieving the attention of scholars worldwide.

Despotic leadership is unarguably becoming relevant to corrupt and authoritative top executives and becoming increasingly serious for organizations(Hoobler \& Hu, 2013). This is evident in many corporate scandals one of them is linked to Enron and Worldcom. These controversies captured vast coverage by media. Main reasons for the growing interest in the negative leadership literature includes: costs associated with bad leaders in terms of financial, physical and psychological pay off. Secondly their effects are twofold and severe on emotional and moral aspects of workforce. Some of these outcomes include negative effects on stress, emotional exhaustion and counterproductive work behaviors(Bamberger \& Bacharach, 2006; Harvey et al., 2007). The incredible serious effects and frequent occurrence rate make despotic leadership a concept of much deeper and broader investigation.

This study aims to introduce a brief review of despotic leadership theory and research conducted to create a solid foundation for knowledge. This will facilitate not only theory development process but will also create many insights for future research.

\section{Conclusion}

The aim of this brief review paper was to improve understanding regarding research conducted on several studies related to despotic leadership. Overall, numerous meaningful relationships as well as outcomes of attitudinal and behavioral nature were studied. Current trends and future directions were also discoursed. Lastly, different research gaps were identified that can serve as a call for more theoretical and empirical research work in this specific domain.

\section{References}

Abbas, M., Raja, U., Darr, W., \& Bouckenooghe, D. (2014). Combined effects of perceived politics and psychological capital on job satisfaction, turnover intentions, and performance. Journal of Management, 40(7), 1813-1830.

Adigüzel, A. Z. (2019). Examination of the effects of despotic leadership and strategic human resources management on the employees in the business world. Yönetim ve Ekonomi Araştırmaları Dergisi, $17(1), 20$.

Ahmad Bodla, A., Tang, N., Van Dick, R., \& Mir, U. R. (2019). Authoritarian leadership, organizational citizenship behavior, and organizational deviance: Curvilinear relationships. Leadership \& Organization Development Journal, 40(5), 583-599.

Ahmad, M., Hussain, S., Sulehri, N. A., \& Hussain, I. (2020) Does Psychological Distance obliterate LMX fruits? Mediating Role of Perceptions of Task Identity. International Review of Social Sciences, 8(7), 108-117.

Akdeniz University, Kasalak, G., \& BiLgiN Aksu, M. (2014). The Relationship between Perceived Organizational Support and Organizational Cynicism of Research Assistants. Educational Sciences: Theory \& Practice, 14(1).

Antonakis, J., Day, D. V., \& Schyns, B. (2012). Leadership and individual differences: At the cusp of a renaissance. Elsevier.

Aquino, K., \& Thau, S. (2009). Workplace victimization: Aggression from the target's perspective. Annual Review of Psychology, 60, 717-741.

Aronson, E. (2001). Integrating leadership styles and ethical perspectives. Canadian Journal of Administrative Sciences/Revue Canadienne Des Sciences de l'Administration, 18(4), 244-256.

Arslan, M. (2018). Organizational cynicism and employee performance: Moderating role of employee engagement. Journal of Global Responsibility, 9(4), 415-431. 
Baig,M. M. A.,Hussain,S., Hussain, I. (2020) Confrontational Phases and Imperfections of OrganizationalInjustice in the workspace (Validation from Government-Sector Development Financial Institutions of Pakistan). International Review of Management and Business Research, 9(2), 207-217.

Bass, B. M., \& Bass, R. (2009). The Bass handbook of leadership: Theory, research, and managerial applications. Simon and Schuster.

Batistič, S., Černe, M., \& Vogel, B. (2017). Just how multi-level is leadership research? A document cocitation analysis 1980-2013 on leadership constructs and outcomes. The Leadership Quarterly, 28(1), 86-103.

Bhandarker, A., \& Rai, S. (2019). Toxic leadership: Emotional distress and coping strategy. International Journal of Organization Theory \& Behavior, 22(1), 65-78.

Bligh, M. C., Kohles, J. C., Pearce, C. L., Justin, J. E., \& Stovall, J. F. (2007). When the romance is over: Follower perspectives of aversive leadership. Applied Psychology, 56(4), 528-557.

Bortolon, C., Lopes, B., Capdevielle, D., Macioce, V., \& Raffard, S. (2019). The roles of cognitive avoidance, rumination and negative affect in the association between abusive supervision in the workplace and non-clinical paranoia in a sample of workers working in France. Psychiatry Research, 271, 581-589.

Boudrias, J.-S., Rousseau, V., \& Lajoie, D. (2020). How Lack of Integrity and Tyrannical Leadership of Managers Influence Employee Improvement-Oriented Behaviors. Journal of Business Ethics.

Brown, M., Kraimer, M. L., \& Bratton, V. K. (2019). The influence of employee performance appraisal cynicism on intent to quit and sportsmanship. Personnel Review, 49(1), 1-18.

Chan, M. E., \& McAllister, D. J. (2014). Abusive supervision through the lens of employee state paranoia. Academy of Management Review, 39(1), 44-66.

Christie, R., \& Geis, F. L. (1970). Chapter I-why machiavelli? Studies in Machiavellianism, 1-9.

De Clercq, D., Azeem, M. U., Haq, I. U., \& Bouckenooghe, D. (2020). The stress-reducing effect of coworker support on turnover intentions: Moderation by political ineptness and despotic leadership. Journal of Business Research, 111, 12-24.

De Clercq, D., Fatima, T., \& Jahanzeb, S. (2019). Ingratiating with Despotic Leaders to Gain Status: The Role of Power Distance Orientation and Self-enhancement Motive. Journal of Business Ethics.

De Clercq, D., Haq, I. U., Raja, U., Azeem, M. U., \& Mahmud, N. (2018). When is an Islamic work ethic more likely to spur helping behavior? The roles of despotic leadership and gender. Personnel Review, 47(3), 630-650.

De Hoogh, A. H. B., \& Den Hartog, D. N. (2008). Ethical and despotic leadership, relationships with leader's social responsibility, top management team effectiveness and subordinates' optimism: A multi-method study. The Leadership Quarterly, 19(3), 297-311.

De Vries, M. F. K., \& Miller, D. (1985). Narcissism and leadership: An object relations perspective. Human Relations, 38(6), 583-601.

De Vries, M. F. R. K. (2006). The spirit of despotism: Understanding the tyrant within. Human Relations, 59(2), 195-220.

De Vries, R. E. (2012). Personality predictors of leadership styles and the self-other agreement problem. The Leadership Quarterly, 23(5), 809-821.

Decoster, S., Stouten, J., Camps, J., \& Tripp, T. M. (2014). The role of employees' OCB and leaders' hindrance stress in the emergence of self-serving leadership. The Leadership Quarterly, 25(4), 647659.

Derogatis, L. R., \& Melisaratos, N. (1983). The brief symptom inventory: An introductory report. Psychological Medicine, 13(3), 595-605.

Eagly, A. H., \& Crowley, M. (1986). Gender and helping behavior: A meta-analytic review of the social psychological literature. Psychological bulletin, 100(3), 283.

Einarsen, Ståle, Aasland, M. S., \& Skogstad, A. (2007). Destructive leadership behavior: A definition and conceptual model. The Leadership Quarterly, 18(3), 207-216.

Erkutlu, H., \& Chafra, J. (2018). Despotic leadership and organizational deviance: The mediating role of organizational identification and the moderating role of value congruence. Journal of Strategy and Management, 11(2), 150-165. 
Feather, N. T. (2006). Deservingness and emotions: Applying the structural model of deservingness to the analysis of affective reactions to outcomes. European Review of Social Psychology, 17(1), 38-73.

Fiedler, F. E., \& Garcia, J. E. (1987). New approaches to effective leadership: Cognitive resources and organizational performance. New York: Wiley

Freeman, D., \& Garety, P. A. (1999). Worry, worry processes and dimensions of delusions: An exploratory investigation of a role for anxiety processes in the maintenance of delusional distress. Behavioral and Cognitive Psychotherapy, 27(1), 47-62.

Freeman, D., McManus, S., Brugha, T., Meltzer, H., Jenkins, R., \& Bebbington, P. (2011). Concomitants of paranoia in the general population. Psychological medicine, 41(5), 923.

Garety, P. A., \& Freeman, D. (1999). Cognitive approaches to delusions: A critical review of theories and evidence. British Journal of Clinical Psychology, 38(2), 113-154.

Gibb, C. A. (1947). The principles and traits of leadership. Journal of Abnormal \& Social Psychology, 4 , 267-284.

Gillet, N., Fouquereau, E., Lequeurre, J., Bigot, L., \& Mokounkolo, R. (2012). Validation d'une échelle de frustration des besoins psychologiques au travail (EFBPT). Psychologie Du Travail et Des Organizations, 18(4), 328-344.

Giessner, S. R., \& Schubert, T. W. (2007). High in the hierarchy: How vertical location and judgments of leaders' power are interrelated. Organizational Behavior and Human Decision Processes, 104(1), 3044.

Gooty, J., \& Yammarino, F. J. (2011). Dyads in organizational research: Conceptual issues and multilevel analyses. Organizational Research Methods, 14(3), 456-483.

Greenbaum, R. L., Mawritz, M. B., \& Piccolo, R. F. (2015). When leaders fail to "walk the talk" supervisor undermining and perceptions of leader hypocrisy. Journal of Management, 41(3), 929-956.

Harvey, P., Stoner, J., Hochwarter, W., \& Kacmar, C. (2007). Coping with abusive supervision: The neutralizing effects of ingratiation and positive affect on negative employee outcomes. The Leadership Quarterly, 18(3), 264-280.

Hogan, R., Curphy, G. J., \& Hogan, J. (1994). What we know about leadership: Effectiveness and personality. American Psychologist, 49(6), 493.

Hoobler, J. M., \& Hu, J. (2013). A model of injustice, abusive supervision, and negative affect. The Leadership Quarterly, 24(1), 256-269.

House, R. J., \& Aditya, R. N. (1997). The social scientific study of leadership: Quo vadis? Journal of Management, 23(3), 409-473.

Hussain, S., \& Dar, I. B. (2020). Comments on "The nature of theory in information systems." Future Business Journal, 6(1), 1-3.

Hussain, I., Ahmed, Q. M., Gulzar, A., Usman, U., \& Hussain, S. (2020). Group cohesion: a therapy against abusive supervision. International Transaction Journal of Engineering, Management, \& Applied Sciences \& Technologies, 1-9.

Huyghebaert, T., Gillet, N., Fernet, C., Lahiani, F.-J., \& Fouquereau, E. (2018). Leveraging psychosocial safety climate to prevent ill-being: The mediating role of psychological need thwarting. Journal of Vocational Behavior, 107, 111-125.

Islam, T., Ahmed, I., Ali, M., Ahmer, Z., \& Usman, B. (2020). Understanding despotic leadership through the lens of Islamic work ethics. Journal of Public Affairs.

Jabeen, R., \& Rahim, N. (2021). Exploring the effects of despotic leadership on employee engagement, employee trust and task performance. Management Science Letters, 223-232.

Jenkins, W. O. (1947). A review of leadership studies with particular reference to military problems. Psychological Bulletin, 44, 54-79.

Jiang, H., Chen, Y., Sun, P., \& Yang, J. (2017). The Relationship between Authoritarian Leadership and Employees' Deviant Workplace Behaviors: The Mediating Effects of Psychological Contract Violation and Organizational Cynicism. Frontiers in Psychology, 8, 732.

Johns, L. C., \& Van Os, J. (2001). The continuity of psychotic experiences in the general population. Clinical Psychology Review, 21(8), 1125-1141. 
Johnson, J. L., \& O’Leary-Kelly, A. M. (2003). The effects of psychological contract breach and organizational cynicism: Not all social exchange violations are created equal. Journal of Organizational Behavior: The International Journal of Industrial, Occupational and Organizational Psychology and Behavior, 24(5), 627-647.

Katz, D., Maccoby, N., Gurin, G., \& Floor, L. (1951). Productivity, supervision, and morale among railroad workers. Ann Arbor, MI: Institute for Social Research.

Kim, J., Yammarino, F. J., Dionne, S. D., Eckardt, R., Cheong, M., Tsai, C.-Y., Guo, J., \& Park, J. W. (2020). State-of-the-science review of leader-follower dyads research. The Leadership Quarterly, 31(1), 101306.

Kipfelsberger, P., \& Kark, R. (2018). 'Killing Me Softly With His/Her Song': How Leaders Dismantle Followers' Sense of Work Meaningfulness. Frontiers in Psychology, 9, 654.

Kipnis, D., Castell, J., Gergen, M., \& Mauch, D. (1976). Metamorphic effects of power. Journal of Applied Psychology, 61(2), 127.

Kipnis, D., Schmidt, S., Price, K., \& Stitt, C. (1981). Why I do like thee: Is it your performance or my orders? Journal of Applied Psychology, 66(3), 324.

Krasikova, D. V., Green, S. G., \& LeBreton, J. M. (2013). Destructive Leadership: A Theoretical Review, Integration, and Future Research Agenda. Journal of Management, 39(5), 1308-1338.

Krasikova, D. V., \& LeBreton, J. M. (2012). Just the two of us: Misalignment of theory and methods in examining dyadic phenomena. Journal of applied psychology, 97(4), 739.

Levinson, H. (1978). Abrasive Personality at Office. Psychology Today, 11(12), 78.

Lipman-Blumen, J. (2005). The allure of toxic leaders: Why followers rarely escape their clutches. Ivey Business Journal, 69(3), 1-40.

Lubit, R. (2004). The tyranny of toxic managers: Applying emotional intelligence to deal with difficult personalities. Ivey Business Journal, 68(4), 1-7.

Mackey, J. D., Parker Ellen, B., McAllister, C. P., \& Alexander, K. C. (2020). The dark side of leadership: A systematic literature review and meta-analysis of destructive leadership research. Journal of Business Research,

McCall, M. W., \& Lombardo, M. M. (1983). Off the track: Why and how successful executives get derailed. Center for Creative Leadership.

Naseer, S., Raja, U., Syed, F., Donia, M. B. L., \& Darr, W. (2016). Perils of being close to a bad leader in a bad environment: Exploring the combined effects of despotic leadership, leader member exchange, and perceived organizational politics on behaviors. The Leadership Quarterly, 27(1), 14-33.

Naseer, S., Syed, F., Nauman, S., Fatima, T., Jameel, I., \& Riaz, N. (2020). Understanding how leaders' humility promotes followers' emotions and ethical behaviors: Workplace spirituality as a mediator. The Journal of Positive Psychology, 15(3), 407-419.

Nauman, S., Fatima, T., \& Haq, I. (2018a). How Despotic Leadership Harms Employee Life: The Roles of Emotional Exhaustion and Trait Anxiety. Academy of Management Proceedings, 2018(1), 15738.

Nauman, S., Fatima, T., \& Haq, I. U. (2018b). Does Despotic Leadership Harm Employee Family Life: Exploring the Effects of Emotional Exhaustion and Anxiety. Frontiers in Psychology, 9, 601.

Nauman, S., Zheng, C., \& Basit, A. A. (2020). How despotic leadership jeopardizes employees' performance: The roles of quality of work life and work withdrawal. Leadership \& Organization Development Journal,

Padilla, A., Hogan, R., \& Kaiser, R. B. (2007). The toxic triangle: Destructive leaders, susceptible followers, and conducive environments. The Leadership Quarterly, 18(3), 176-194.

Paglis, L. L., \& Green, S. G. (2002). Leadership self-efficacy and managers' motivation for leading change. Journal of Organizational Behavior: The International Journal of Industrial, Occupational and Organizational Psychology and Behavior, 23(2), 215-235.

Podsakoff, P. M., MacKenzie, S. B., Lee, J.-Y., \& Podsakoff, N. P. (2003). Common method biases in behavioral research: A critical review of the literature and recommended remedies. Journal of Applied Psychology, 88(5), 879-903. 
Raja, U., Haq, I. U., De Clercq, D., \& Azeem, M. U. (2020). When ethics create misfit: Combined effects of despotic leadership and Islamic work ethic on job performance, job satisfaction, and psychological well-being. International Journal of Psychology, 55(3), 332-341.

Rasool, G., Naseer, S., Syed, F., \& Ahmad, I. (2020). Despotic Leadership and Employees' Outcomes: Mediating Effect of Impression Management. 24. Pakistan Journal of Commerce and Social Sciences, 12(3), 784-806.

Ray, J. J. (1976). Do authoritarians hold authoritarian attitudes? Human Relations, 29(4), 307-325.

Richter, M. (1990). Aristotle and the classical Greek concept of despotism. History of European Ideas, 12(2), 175-187.

Rus, D., Van Knippenberg, D., \& Wisse, B. (2010). Leader power and leader self-serving behavior: The role of effective leadership beliefs and performance information. Journal of Experimental Social Psychology, 46(6), 922-933.

Ryan, R. M. (1995). Psychological needs and the facilitation of integrative processes. Journal of Personality, 63(3), 397-427.

Ryan, R. M., \& Deci, E. L. (2000). The darker and brighter sides of human existence: Basic psychological needs as a unifying concept. Psychological Inquiry, 11(4), 319-338.

Sarmad, M., Qayyum, A., Shafi, M., Hussain, S., \& Rehman, S. (2020). Investigating moderating role of emotional intelligence among counterproductive work behavior, work interference and negative emotions in development sector of Pakistan. Management Science Letters, 11(4), 1093-1100.

Schilling, J. (2009). From Ineffectiveness to Destruction: A Qualitative Study on the Meaning of Negative Leadership. Leadership, 5(1), 102-128.

Schyns, B., \& Schilling, J. (2013a). How bad are the effects of bad leaders? A meta-analysis of destructive leadership and its outcomes. The Leadership Quarterly, 24(1), 138-158.

Sekaran, U., \& Bougie, R. (2016). Research methods for business: A skill building approach. John Wiley \& Sons.

Shackleton, V. (1995). Leaders who derail. Business Leadership, 89-100.

Shamir, B., House, R. J., \& Arthur, M. B. (1993). The motivational effects of charismatic leadership: A self-concept based theory. Organization Science, 4(4), 577-594.

Shao, P., Li, A., \& Mawritz, M. (2018). Self-protective reactions to peer abusive supervision: The moderating role of prevention focus and the mediating role of performance instrumentality. Journal of Organizational Behavior, 39(1), 12-25.

Sharma, P. N. (2018). Moving beyond the employee: The role of the organizational context in leader workplace aggression. The Leadership Quarterly, 29(1), 203-217.

Smith, R. H., Powell, C. A., Combs, D. J., \& Schurtz, D. R. (2009). Exploring the when and why of schadenfreude. Social and Personality Psychology Compass, 3(4), 530-546.

Stansfeld, S., \& Candy, B. (2006). Psychosocial work environment and mental health-A meta-analytic review. Scandinavian Journal of Work, Environment \& Health, 443-462.

Stogdill, R. M. (1948). Personal factors associated with leadership: A survey of the literature. Journal of Psychology, 25, 35-71.

Stratman, J. L., \& Youssef-Morgan, C. M. (2019). Can positivity promote safety? Psychological capital development combats cynicism and unsafe behavior. Safety Science, 116, 13-25.

Syed, F., Akhtar, M. W., Kashif, M., Asrar-ul-Haq, M., ain, Q. ul, Husnain, M., \& Aslam, M. K. (2020). When leader is morally corrupt: Interplay of despotic leadership and self-concordance on moral emotions and bullying behavior. Journal of Management Development, 39(7/8), 911-928.

Tepper, B. J. (2000). Consequences of abusive supervision. Academy of Management Journal, 43(2), 178190.

Tepper, B. J. (2007). Abusive supervision in work organizations: Review, synthesis, and research agenda. Journal of Management, 33(3), 261-289.

Thompson, V. A. (1965). Bureaucracy and innovation. Administrative Science Quarterly, 1-20.

Thoroughgood, C. N., Sawyer, K. B., Padilla, A., \& Lunsford, L. (2018). Destructive Leadership: A Critique of Leader-Centric Perspectives and Toward a More Holistic Definition. Journal of Business Ethics, 151(3), 627-649. 
Trépanier, S.-G., Fernet, C., \& Austin, S. (2016). Longitudinal relationships between workplace bullying, basic psychological needs, and employee functioning: A simultaneous investigation of psychological need satisfaction and frustration. European Journal of Work and Organizational Psychology, 25(5), 690-706..

Tufail, M., Hussain, S., Hayat, M.,Qadir,A.(2020) Workplace incivility and Organization Citizenship Behaviour:The Role of Burnout and Islamic Work Ethic. International Review of Social Sciences, 8(8), 21-28.

Turchetti, M. (2008). 'Despotism'and'Tyranny'Unmasking a Tenacious Confusion. European Journal of Political Theory, 7(2), 159-182.

Van Dijk, W. W., Ouwerkerk, J. W., Goslinga, S., Nieweg, M., \& Gallucci, M. (2006). When people fall from grace: Reconsidering the role of envy in schadenfreude. Emotion, 6(1), 156.

Vansteenkiste, M., \& Ryan, R. M. (2013). On psychological growth and vulnerability: Basic psychological need satisfaction and need frustration as a unifying principle. Journal of Psychotherapy Integration, 23(3), 263-287.

Wageman, R., Hackman, J. R., Nohria, N., \& Khurana, R. (2010). What makes teams of leaders leadable? Advancing leadership. 433.

Wilkerson, J. M., Evans, W. R., \& Davis, W. D. (2008). A Test of Coworkers' Influence on Organizational Cynicism, Badmouthing, and Organizational Citizenship Behavior. Journal of Applied Social Psychology, 38(9), 2273-2292.

Yam, K. C., Christian, M. S., Wei, W., Liao, Z., \& Nai, J. (2018). The mixed blessing of leader sense of humor: Examining costs and benefits. Academy of Management Journal, 61(1), 348-369.

Yang, C., Chen, Y., Zhao Roy, X., \& Mattila, A. S. (2020). Unfolding deconstructive effects of negative shocks on psychological contract violation, organizational cynicism, and turnover intention. International Journal of Hospitality Management, 89,

Yukl, G., \& Mahsud, R. (2010). Why flexible and adaptive leadership is essential. Consulting Psychology Journal: Practice and Research, 62(2), 81-96.

Zapata, C. P., \& Hayes-Jones, L. C. (2019). The consequences of humility for leaders: A double-edged sword. Organizational Behavior and Human Decision Processes, 152, 47-63.

Zhu, J., Song, L. J., Zhu, L., \& Johnson, R. E. (2019). Visualizing the landscape and evolution of leadership research. The Leadership Quarterly, 30(2), 215-232. 